\title{
HUBUNGAN PENDAMPINGAN ORANG TUA DENGAN TINGKAT KOOPERATIF ANAK USIA PRASEKOLAH SELAMAPEMBERIAN TINDAKAN INVASIF \\ INJEKSIINTRAVENA DI RUANG IGD \\ RSUD ARJAWINANGUN
}

\author{
Ayu Yuliani S. \\ Dosen Jurusan Keperawatan Poltekkes Kemenkes Tasikmalaya
}

\begin{abstract}
ABSTRAK
Penelitian ini bertujuan untuk mengetahui hubungan pendampingan orang tua dengan tingkat kooperatif anak usia prasekolah (3-6) tahun selama pemberian tindakan invasif injeksi intravena di ruang IGD RSUD Arjawinangun. Jenis penelitian yang dilakukan adalah deskriptif korelasi dengan pendekatan cross sectional. Jumlah sampel sebanyak 30 anak dengan teknik pengambilan sampling menggunakan consecutive sampling. Hasil penelitian menunjukkan bahwa anak-anak lebih banyak didampingi oleh orang tuanya $20(66,3 \%)$ responden dari 30 responden yang diteliti. Ditemukan hubungan antara pendampingan orang tua dengan tingkat kooperatif anak ( $p$ value 0,050$)$. Usia anak berhubungan dengan tingkat kooperatif anak ( $r$ hitung 0,569, $\rho$-value 0,001), dan ditemukan hubungan antara pengalaman hospitalisasi sebelumnya dengan tingkat kooperatif anak ( $p$ value 0,023 ). Tidak ditemukan hubungan antara jenis kelamin dengan tingkat kooperatif anak ( $p$ value 0,705 ).Pendampingan orang tua, usia, dan pengalaman hospitalisasi merupakan faktor yang mempengaruhi tingkat kooperatif anak Faktor dominan yang mempengaruhi tingkat kooperatif anak ialah usia ( $p$ value 0,001 ) Rekomendasi dari penelitian ini ialah perlu dilakukan penelitian lebih lanjut dengan jumlah sampel dan variabel yang lebih besar terhadap tingkat kooperatif anak yang dirawat di ruang anak dengan menggunakan metode eksperimen.
\end{abstract}

Kata Kunci : Pendampingan orang tua, tingkat kooperatif, anak usia prasekolah, tindakan invasif, injeksi intravena.

\begin{abstract}
This studyaimed to determine thementoring relationship with aparent cooperative preschool agelevel (3-6) years during the giving of invasive intravenous injection in hospital Erroom Arjawinangun. Type of research was crosssectional descriptive correlation study. The total sample of 30 children with a sampling technique used aconsecutive sampling. Results showed that more children accompanied by their parents 20 (66.3\%) of respondents from 30 respondents surveyed. Found mentoring relationships between parents and children cooperative level ( $\rho$ value 0.050). Age children associated with the level of cooperative children $(r=0,569, \rho$ value $=0.001)$, and found the relationship between previous hospitalization experience with cooperative child level ( $\rho$-value 0.023). No relationship was found between the sexes with the level of cooperative children ( $\rho$-value 0.705$)$. Researchers concluded that the assistance of parents, age, and hospitalization experienceis a factor that affect sthe level of cooperative child dominant factor affec ting the level of cooperative child is age ( $\rho$-value 0.001). Recommendations from this study is that further research needs to be done with a variable number of samples and the greater the level of cooperative children admitted in the nursery by using experimental methods.
\end{abstract}

Keywords : Parent mentoring, level cooperative, preschooler, invasive measures, intravenous injection. 
Ayu Yuliani S., Poltekkes Tasikmalaya.; Pendampingan, kooperatif, usia prasekolah, invasif,

\section{PENDAHULUAN}

Anak adalah makhluk unik yang memiliki kebutuhan berbeda disetiap tahap tumbuh dan kembangnya, dan anak bukanlah orang dewasa kecil. Oleh karena itu orang tua perlu memahami pentingnya menyediakan fasilitas untuk mendukung menuju pertumbuhan dan perkembangan anak (Cahyaningrum, 2011). Untuk mencapai tumbuh dan kembang anak secara sehat maka wajib dibesarkan dan diasuh dengan penuh tanggung jawab (UU RI No. 36, 2009).

Sakit dan dirawat di rumah sakit merupakan suatu bentuk krisis atau stressor utama yang terlihat pada anak. Anak-anak sangat rentan terhadap krisis penyakit dan hospitalisasi yang disebabkan oleh adanya stress akibat perubahan keadaan sehat dan rutinitas lingkungan di rumah sakit, serta keterbatasan anak dalam mekanisme pertahanan untuk menghadapi stressor (Wong et al., 2009). Hospitalisasi merupakan keadaan pasien yang dirawat di rumah sakit karena berbagai alasan seperti prosedur atau pembedahan, perawatan medis darurat, pengobatan, serta memonitor dan menstabilkan kondisi yang ada (Costello, 2008).

Dalam kondisi seperti ini persepsi anak terhadap penyakit bervariasi. $\mathrm{Hal}$ ini dipengaruhi oleh tahapan usia perkembangan anak, pengalaman sebelumnya terhadap sakit, sistem pendukung yang ada, dan kemampuan koping anak (Hockenberry, \& Wilson, 2009).Sebagai perawat anak perlu memahami faktor-faktor yang menyebabkan stress dan respon anak selama dirawat di rumah sakit sesuai tahap perkembangan anak.

Pengalaman yang tidak menyenangkan bagi anak usia prasekolah, usia sekolah dan keluarga adalah dirawat di rumah sakit. Perawatan di rumah sakit menimbulkan reaksi tertentu yang akan berdampak pada kerja sama anak dan orang tua dalam perawatan selama di rumah sakit. Selama di rumah sakit rasa sakit, berpisah dari orang tuanya menjadi stressor bagi anak dan stress tersebut akan menyebabkan kecemasan juga pada orang tua (Nursalam, 2005).
Hospitalisasi dapat ditunjukan dengan reaksi agresif dengan marah dan berontak, ekspresi verbal dengan mengucapkan katakata marah, tidak mau bekerja sama dengan perawat dan ketergantungan pada orang tua. Anak prasekolah juga sering mengalami kehilangan kontrol pada dirinya dan rasa cemas ini muncul akibat adanya pembatasan aktivitas yang menganggap bahwa tindakan dan prosedur perawatan dapat mengancam integritas tubuhnya (Supartini, 2004)

Perawatan anak prasekolah di rumah sakit merupakan pengalaman yang penuh dengan stress. Beberapa bukti ilmiah menunjukkan bahwa lingkungan rumah sakit sendiri merupakan penyebab stress bagi anak baik lingkungan fisik rumah sakit seperti bangunan, ruang rawat, alat-alat, bau yang khas, pakaian putih petugas kesehatan maupun lingkungan sosial seperti sesama pasien anak ataupun interaksi dan sikap petugas kesehatan itu sendiri. Selain itu faktor penyebab stress hospitalisasi pada anak antara lain berpisah dengan keluarga, kurang informasi dan prosedur pengobatan (Supartini, 2004).

Dirumah sakit anak harus menghadapi lingkungan yang asing dan pemberi asuhan yang tidak di kenal. Sering kali anak harus mengalami prosedur yang mengalami nyeri, kehilangan kemandirian dan berbagai hal yang tidak diketahui. Interpretasi mereka terhadap kejadian, respon anak terhadap pengalaman dan signifikansi yang anak tempatkan pada pengalaman ini secara langsung berhubungan dengan tingkat perkembangan (Wong \& Hockenberry, M, dkk 2008)

Hubungan anak dan orang tua adalah unik, berbeda antara yang satu dengan yang lainnya. Orang tua, keluarga, dan tenaga kesehatan mempunyai kewajiban untuk memberikan pengasuhan dan pelayanan yang optimal sehingga dapat terpenuhi segala kebutuhan sesuai dengan tahap pertumbuhan dan perkembangan.

Anak-anak yang dirawat di rumah sakit dalam dua dekade terakhir mengalami peningkatan pesat. Prosentase anak-anak 
Ayu Yuliani S., Poltekkes Tasikmalaya.; Pendampingan, kooperatif, usia prasekolah, invasif,

yang dirawat di rumah sakit ini mengalami masalah yang lebih serius dan kompleks dibandingkan dengan hospitalisasi tahuntahun sebelumnya (Wong, et, al, 2009). Data

\section{METODE PENELITIAN}

Rancangan yang digunakan dalam penelitian ini adalah dengan metode deskriptif korelasi yang bertujuan untuk mengetahui hubungan pendampingan orang tua terhadap tingkat kooperatif anak usia prasekolah (3-6) tahun selama pemberian tindakan invasif injeksi intravena di IGD RSUD Arjawinangun Kabupaten Cirebon.

Pendekatan yang digunakan dalam penelitian adalah pendekatan potong lintang (cross sectional) yaitu suatu jenis pendekatan yang menekankan waktu pengukuran/observasi data variabel independen dan dependen hanya satu kali pada satu saat (Nursalam, 2013). profil kesehatan kabupaten Cirebon 2011 pada tahun 2011 angka kesakitan anak sebesar $25,07 \%$ dari jumlah 637.603 anak usia 0-14 tahun di kabupaten Cirebon

Pengambilan sampel dalam penelitian ini berdasarkan cara consecutive sampling. Jumlah sampel yang dibutuhkan keseluruhan setelah ditambah drop out adalah 30 anak.

Tingkat kooperatif dilihat dengan mengunakan lembar observasi Wright dilihat mulai dari skala 1 sampai dengan 3 , dan skala perilaku sikap kooperatif menggunakan skala Frankl dilihat dengan skala 1 sampai 4

Responden dilakukan observasi saat dilakukan tindakan pemasangan infus dan dilakukan penilaian dengan menngonakan lebar observasi.

\section{HASIL PENELITIAN}

\section{Analisis Univariat :}

Tabel 1. Distribusi Frekuensi Pendampingan Orang Tua di Ruang IGD RSUD Arjawinangun Kabupaten Cirebon

\begin{tabular}{ccc}
\hline Pendampingan Orang Tua & $\mathbf{n}$ & $\%$ \\
\hline Di Dampingi & 20 & 66,7 \\
\hline Tidak Didampingi & 10 & 33,3 \\
\hline Total & $\mathbf{3 0}$ & $\mathbf{1 0 0}$
\end{tabular}

Hasil analisis tabel 1 di atas menunjukkan bahwa distribusi anak yang didamping oleh orang tuanya lebih banyak daripada anak yang tidak didampingi oleh orang tuanya. Dari 30 responden, anak yang didampingi oleh orang tuanya pada saat dilakukan pemberian tindakan invasif injeksi intravena berjumlah 20 anak(66,7\%).

Tabel 2. Distribusi FrekuensiTingkat Kooperatif Anak di Ruang IGD RSUD Arjawinangun Kabupaten Cirebon

\begin{tabular}{ccc}
\hline Tingkat Kooperatif anak & $\mathbf{n}$ & $\%$ \\
\hline Kooperatif & 17 & 56,7 \\
\hline Tidak kooperatif & 13 & 43,3 \\
\hline Total & $\mathbf{3 0}$ & $\mathbf{1 0 0}$ \\
\hline
\end{tabular}

Hasilanalisis tabel 2., di atas menunjukkan bahwa distribusi tingkat kooperatif anak pada saat dilakukan pemberian tindakan invasif injeksi intravena lebih banyak anak yang kooperatif. Dari 30 responden, 17 (56,7 \%) anak kooperatif. sebaran karakteristik responden tampak pada tabel dibawah ini : 
Ayu Yuliani S., Poltekkes Tasikmalaya.; Pendampingan, kooperatif, usia prasekolah, invasif,

Tabel 3. Karekateristik usia responden penelitian

\begin{tabular}{ccc}
\hline UsiaAnak & $\mathbf{n}$ & $\%$ \\
\hline 3 Tahun & 11 & 36,7 \\
4 Tahun & 5 & 16,7 \\
5 Tahun & 6 & 20,0 \\
6 Tahun & 8 & 26,7 \\
\hline Total & $\mathbf{3 0}$ & $\mathbf{1 0 0}$ \\
\hline
\end{tabular}

Hasil analisis tabel 3 di atas menunjukkan bahwa distribusi anak usia 3 tahun lebih banyak dari pada anak yang berusia 4,5 dan 6 tahun. Dari 30 responden anak yang akan dilakukan pemberian tindakan invasif injeksi intravena, 11 (36,7\%) anak berusia 3 tahun.

Tabel 4. Karakteristik jenis kelamin responden

\begin{tabular}{ccc}
\hline Jenis Kelamin & $\mathbf{n}$ & $\%$ \\
\hline Laki-laki & 20 & 66,7 \\
\hline Perempuan & 10 & 33,3 \\
\hline Total & $\mathbf{3 0}$ & $\mathbf{1 0 0}$ \\
\hline
\end{tabular}

Hasil analisis tabel 4 di atas menunjukkan bahwa distribusi jenis kelamin anak lebih banyak yang berjenis kelamin laki- laki dari pada anak yang berjenis kelamin perempuan. Dari 30 responden, 20 (66,7\%) anak berjenis kelamin laki-laki.

Tabel 5. Pengalaman hospitalisasi anak sebelumnya

\begin{tabular}{ccc}
\hline $\begin{array}{c}\text { Pengalaman Hospitalisasi } \\
\text { Anak Sebelumnya }\end{array}$ & $\mathbf{n}$ & $\%$ \\
\hline Sudah & 19 & 63.3 \\
\hline Belum & 11 & 36.7 \\
\hline Jumlah & $\mathbf{3 0}$ & $\mathbf{1 0 0}$ \\
\hline
\end{tabular}

Hasil analisis tabel 5 di atas menunjukkan bahwa distribusi anak yang sudah mengalami hospitalisasi sebelumnya lebih banyak dari pada anak yang belum

\section{Anallisis Bivariat}

Data dari tiga puluh anak yang ikut dalam penelitian ini diolah dengan menggunakan uji Chi Square dengan menggunakan nilai Fisher's Exact Test dan uji mengalami hospitalisasi sebelumnya. Dari 30 responden, 19 (63,3\%) (anak pernah mengalami hospitalisasi).

Tabel 6. Pendampingan orang tua dengan tingkat kooperatif anak

\begin{tabular}{ccccccccc}
\hline \multirow{2}{*}{$\begin{array}{c}\text { Pendampingan } \\
\text { Orang Tua }\end{array}$} & \multicolumn{4}{c}{ Tingkat Kooperatif Anak } & \multicolumn{2}{c}{ Total } & \multirow{2}{*}{$\boldsymbol{\rho}$} \\
\cline { 2 - 7 } & Kooperatif & \multicolumn{2}{c}{$\begin{array}{c}\text { Tidak } \\
\text { Kooperatif }\end{array}$} & & \\
\cline { 2 - 7 } & $\mathbf{n}$ & $\%$ & $\mathbf{n}$ & $\%$ & $\mathbf{n}$ & $\%$ & \\
\hline Didamping & 14 & 70,0 & 6 & 30,0 & 20 & 100 & 0,05 \\
\hline Tidak didampingi & 3 & 30,0 & 7 & 70,0 & 10 & 100 & \\
\hline
\end{tabular}


Ayu Yuliani S., Poltekkes Tasikmalaya.; Pendampingan, kooperatif, usia prasekolah, invasif,

Hasil analisis tabel 6 di atas menunjukkan bahwa dari 20 anak yang didampingi oleh orang tua pada saat dilakukan tindakan invasif injeksi intravena, $14(70,0 \%)$ anak terlihat kooperatif dan 6 $(30,0 \%)$ anak terlihat tidak kooperatif. 10 anak yang tidak didampingi oleh orang tuanya pada saat anak dilakukan tindakan invasif injeksi intravena, $3(30,0 \%)$ anak terlihat kooperatif dan 7 (70,0\%) anak tidak kooperatif. Dari hasil uji Chi Square dengan menggunakan nilai Fisher's Exact Test didapatkan nilai $\rho=0,05$, karena $\rho \leq 0,05$ maka dapat disimpulkan ada hubungan yang bermakna antara pendampingan orang tua dengan tingkat kooperatif anak yang dilakukan tindakan invasif injeksi intravena

Tabel 7.Usia anak dengan tingkat kooperatif anak

\begin{tabular}{|c|c|c|c|c|c|c|c|c|}
\hline \multirow{3}{*}{ Usia } & \multicolumn{4}{|c|}{ Tingkat Kooperatif Anak } & \multirow{2}{*}{\multicolumn{2}{|c|}{ Total }} & \multirow{3}{*}{$\boldsymbol{P}$} & \multirow{3}{*}{$r$} \\
\hline & \multicolumn{2}{|c|}{ Kooperatif } & \multicolumn{2}{|c|}{ Tidak Kooperatif } & & & & \\
\hline & $\mathbf{n}$ & $\%$ & $\mathbf{n}$ & $\%$ & $\mathbf{n}$ & $\%$ & & \\
\hline 3 Tahun & 3 & 27,2 & 8 & 72,7 & 11 & 100 & \multirow{4}{*}{0,01} & \multirow{4}{*}{0,569} \\
\hline 4 Tahun & 2 & 40,0 & 3 & 60,0 & 5 & 100 & & \\
\hline 5 Tahun & 5 & 83,3 & 1 & 16,6 & 6 & 100 & & \\
\hline 6 Tahun & 7 & 87,5 & 1 & 12,5 & 8 & 100 & & \\
\hline
\end{tabular}

Hasil analisis tabel 7 di atas menunjukan anak yang kooperatif berusia 3 tahun berjumlah $3(27,2 \%)$, anak berusia 4 tahun berjumlah $2(40,0 \%)$, anak berusia 5 tahun berjumlah $5(83,3 \%)$ dan anak berusia 6 tahun berjumlah $7 \quad(87,5 \%)$ anak. Sedangkan anak yang tidak kooperatif berusia 3 tahun berjumlah $8(72,7 \%)$, anak 4 tahun berjumlah $3(60,0 \%)$, anak 5 tahun berjumlah $1(16,6 \%)$ dan 6 tahun berjumlah 1 $(12,5 \%)$ anak. Dari hasil uji korelasi person didapatkan nilai $r$; 0,569 sehingga intepretasi hasil penelitian tersebut sedang dengan $\rho$ value $0,01<0,05$ maka sesuai dengan ketentuan bahwa apabila nilai $\rho \leq 0,05$ maka terdapat korelasi yang bermakna antara 2 variabel. Nilai signifikasi positif menunjukan semakin besar variabel pendampingan orang tua akan semakin besar hubungan tingkat kooperatif anak yang dilakukan injeksi intravena

Tabel 8. Jenis kelamin dengan tingkat kooperatif anak

\begin{tabular}{|c|c|c|c|c|c|c|c|}
\hline \multirow{3}{*}{ Jenis Kelamin } & \multicolumn{4}{|c|}{ Tingkat Kooperatif Anak } & \multirow{2}{*}{\multicolumn{2}{|c|}{ Total }} & \multirow{3}{*}{$\boldsymbol{P}$} \\
\hline & \multicolumn{2}{|c|}{ Kooperatif } & \multicolumn{2}{|c|}{ Tidak Kooperatif } & & & \\
\hline & $\mathbf{n}$ & $\%$ & $\mathbf{n}$ & $\%$ & $\mathbf{n}$ & $\%$ & \\
\hline Laki-laki & 12 & 60,0 & 8 & 40,0 & 20 & 100 & \multirow{2}{*}{0,705} \\
\hline Perempuan & 5 & 50,0 & 5 & 50,0 & 10 & 100 & \\
\hline
\end{tabular}

Hasil analisis tabel 8 di atas menunjukan anak yang berjenis kelamin lakilaki berjumlah 20 anak, $12(60,0 \%)$ anak kooperatif dan $8 \quad(40,0 \%)$ anak tidak kooperatif sedangkan berjenis kelamin perempuan berjumlah 10 anak, 5 (50,0\%) anak anak kooperatif dan $5(50,0 \%)$ anak tidak kooperatif. Dari hasil uji Chi Square dengan menggunakan nilai Fisher's Exact Test didapatkan nilai $\rho=0,705$, karena $\rho>$ 0,05 , maka dapat disimpulkan tidak ada hubungan yang bermakna antara jenis kelamin dengan tingkat kooperatif anak yang dilakukan tindakan invasif injeksi intravena.

Hasil analisis table 9 di bawah, menunjukan anak yang pengalaman hospitalisasi sebelumnya berjumlah 19 anak, $14(73,7 \%)$ anak kooperatif dan 5 (26,3\%) anak tidak kooperatif sedangkan anak yang belum pernah mengalami hospitalisasi sebelumnya berjumlah 11 anak, 3 (27,3\%) anak anak kooperatif dan $8(72,7 \%)$ anak 
Ayu Yuliani S., Poltekkes Tasikmalaya.; Pendampingan, kooperatif, usia prasekolah, invasif,

tidak kooperatif. Dari hasil uji Chi Square dengan menggunakan nilai Fisher's Exact Test didapatkan nilai $\rho=0,023$, karena $\rho \leq$ 0,05 maka dapat disimpulkan ada hubungan yang bermakna antara pengalaman hospitalisasi sebelumnya dengan tingkat kooperatif anak yang dilakukan tindakan invasif injeksi intravena.

Tabel 9. Pengalaman hospitalisasi sebelumnya dengan tingkat kooperatif anak

\begin{tabular}{ccccccccc}
\hline \multirow{2}{*}{$\begin{array}{c}\text { Pengalaman } \\
\text { Hospitalisasi } \\
\text { Sebelumnya }\end{array}$} & \multicolumn{4}{c}{ Tingkat Kooperatif Anak } & \multicolumn{2}{c}{ Total } & \multirow{2}{*}{$\boldsymbol{p}$} \\
\cline { 2 - 6 } & \multicolumn{2}{c}{ Kooperatif } & \multicolumn{2}{c}{$\begin{array}{c}\text { Tidak } \\
\text { Kooperatif }\end{array}$} & & & \\
\cline { 2 - 7 } & $\mathbf{n}$ & $\%$ & $\mathbf{n}$ & $\%$ & $\mathbf{n}$ & $\%$ & \\
\hline Sudah & 14 & 73,7 & 5 & 26,3 & 19 & 100 & 0,023 \\
Belum & 3 & 27,3 & 8 & 72,7 & 11 & 100 & \\
\hline
\end{tabular}

\section{PEMBAHASAN}

Hasil penelitian menunjukan bahwa dari 30 responden, $20(66,7 \%)$ anak didampingi oleh orang tuanya selama pemberian tindakan invasif injeksi intravena di ruang IGD RSUD Arjawinangun Kabupaten Cirebon sehingga dapat disimpulkan bahwa sebagian responden didampingi oleh orang tuanya. Hal ini menunjukan bahwa anak membutuhkan orang tua selama hospitalisasi (Supartini, 2004). kehadiran orang tua yaitu ayah dan ibu sangatlah besar artinya bagi perkembangan kepribadian seorang anak. Orang tua cenderung bersikap lebih melindungi pada anaknya yang terkena penyakit (Gunarsa, 2008).

Perilaku kooperatif menunjukkan bahwa sebagian besar anak kooperatif selama pemberian tindakan invasif injeksi intravena di ruang IGD. Dari 30 anak, 17 (56,7\%) anak kooperatif. Dalam penelitian ini sikap kooperatif yang ditujukan tidakterlepas dari pendampingan orang tua yang sesuai dengan penerapan prinsip atraumatic care.

Usia menujukkan bahwa anak usia 3 tahun lebih banyak daripada anak yang berusia 4,5 dan 6 tahun. Dari 30 responden anak yang akan dilakukan pemberian tindakan invasif injeksi intravena, 11 (36,7\%) anak berusia 3 tahun dimana anak usia prasekolah $(3-6)$ tahun mempersepsikan hospitalisasi sebagi suatu hukuman sehingga anak akan merasa malu, merasa bersalah, dan takut. Tindakan dan prosedur di rumah sakit dianggap mengancam integritas tubuhnya. Hal ini menimbulkan reaksi agresif dengan marah, berontak, tidak mau bekerja samadengan perawat, dan ketergantungan dengan orang tua (Supartini, 2004).

Jenis kelamin memberikan gambaran lebih banyak anak yang berjenis kelamin lakilaki dari pada anak yang berjenis kelamin perempuan. Dari 30 responden, $20(66,7 \%)$ anak berjenis kelamin laki-laki. Menurut Soetjiningsih 1995, dalam Subandi, 2012) bahwa anak laki-laki lebih sering sakit dibandingkan dengan anak perempuan, tetapi belum tahu penyebabnya. Menurut Subandi (2012) karakteristik anak laki-laki secara umum lebih senang bermain di luar rumah dari pada didalam rumah sehingga mudah terjangkit penyakit.

Pengalaman hospitalisai sebelumnya menunjukkan bahwa distribusi anak yang sudah mengalami hospitalisasi sebelumnya lebih banyak dari pada anak yang belum mengalami hospitalisasi sebelumnya. Dari 30 responden, 19 (63,3\%) anak anak pernah mengalami hospitalisasi. Hal ini dapat memberi gambaran kepada anak tentang apa yang akan dialaminya sehingga akan mempengaruhi respon anak seperti tindakan yang menyakitkan dan pengalaman kemampuan mengendalikan kondisi stress tersebut. Hospitalisasi dan penyakit merupakan pengalaman yang membuat tekanan secara fisik dan psikologis karena perpisahan dari lingkungan yang tidak biasa ditemukan anak. Adanya lingkungan baru 
Ayu Yuliani S., Poltekkes Tasikmalaya.; Pendampingan, kooperatif, usia prasekolah, invasif,

membutuhkan proses adaptasi (Wong, Hockenberry \& Marylin, 2007).

Hubungan pendampingan orang tua dengan tingkat kooperatif anak menunjukkan hasil adanya hubungan yang bermakna antara 2 variabel dengan nilai $\rho$ value $0,050 \leq$ 0,05 . Diaman focus intervensi keperawatan dalam upaya mengatasai masalah yang timbul baik anak maupun orang tua selama hospitalisasi adalah meminimalkan stressor, memaksimalkan manfaat hospitalisasi, memberikan dukungan psikologi terhadap anggota keluarga dan mempersiapkan anak sebelum hospitalisasi (Supartini, 2004).

Kehadiran orang tua yaitu ayah dan ibu sangatlah besar artinya bagi perkembangan kepribadian seorang anak. Orang tua cenderung bersikap lebih melindungi pada anaknya yang terkena penyakit. Orang tua dapat memberikan asuhan yang efektif selama hospitalisasi anaknya. Dengan demikian, tujuan asuhan akan tercapai dengan baik apabila ada kerja sama yang baik antara perawat dengan orang tua (Carpenito, 2009).

Hubungan usia dengan tingkat kooperatif anak dari hasil uji korelasi person diperoleh nilai $r$ hitung 0,569 sehingga intepretasi hasil penelitian sesuai dengan $r$ tabel 0,40-0,599 terdapat hubungan sedang dengan $\rho$ value $0,001,<0,050$ maka terdapat korelasi yang bermakna antara 2 variabel. Nilai signifikasi positif menunjukan semakin besar variabel pendampingan orang tua akan semakin besar hubungan tingkat kooperatif anak yang dilakukan injeksi intravena. Anak usia prasekolah $(3-6)$ tahun mempersepsikan hospitalisasi sebagai suatu hukuman sehingga anak akan merasa malu, merasa bersalah, dan takut. Tindakan dan prosedur di rumah sakit dianggap mengancam integritas tubuhnya. Hal ini menimbulkan reaksi agresif dengan marah, berontak, tidak mau bekerja samadengan perawat, dan ketergantungan dengan orang tua (Supartini, 2004).

Hubungan jenis kelamin dengan tingkat koopeartif menunjukan anak yang berjenis kelamin laki-laki dengan prosentase $60,0 \%$ kooperatif sedangkan berjenis kelamin perempuan, 50,0\% anak kooperatif. Dari hasilujiChi Square dengan menggunakan nilai Fisher's Exact Testdidapatkan nilai $\rho 0,705$ > 0,05 . Sehingga dapat disimpulkan tidak ada hubungan yang bermakna antara jenis kelamin dengan tingkat kooperatif anak yang dilakukan tindakan invasif injeksi intravena.

Hubungan pengalaman hospitalisasi sebelumnya dengan tingkat kooperatif anak menunjukan anak yang mempunyai pengalaman hospitalisasi sebelumnya dengan prosentase $73,7 \%$ kooperatif sedangkan anak yang belum pernah mengalami hospitalisasi sebelumnya dengan prosentase 27,3\% anak kooperatif. Dari hasilujiChi Square dengan menggunakan nilai Fisher's Exact Testdidapatkan nilai $\rho=0,023$ $\leq 0,05$. Sehingga dapat disimpulkan ada hubungan yang bermakna antara pengalaman hospitalisasi sebelumnya dengan tingkat kooperatif anak yang dilakukan tindakan invasif injeksi intravena.Apabila anak pernah mengalami pengalaman tidak menyenangkan selama dirawat di rumah sakit sebelumnya, maka akan menyebabkan anak tidak kooperatif dengan perawat dan dokter. Begitu juga sebaliknya apabila anak di rumah sakit mendapatkan perawatan yang baik dan menyenangkan, maka ana akan lebih kooperatif kepada perawat dan dokter (Supartini, 2004).

Pada anak yang sudah mempunyai pengalaman hospitalisasi sebelumnya, anak sudah memasuki tahap menerima sehingga anak menunjukan perilaku secara samar mulai menerima perpisahan, membina hubungan secara dangkal dan anak mulai terlihat menyukai lingkungannya (Supartini, 2004). Anak mulai berinteraksi dengan orang lain atau pemberi asuhan yang dikenalnya, mulai membentuk hubungan baru, tapi bersifat superfisial (Wong, Hockenberry \& Marylin, 2007). Anak juga mulai ada perasaan dan ini jarang terlihat pada anak yang dihospitalisasi. Perasaan senang ini terjadi karena anak mulai bisa mengerti alas an dari perawatannya (Hockenberry \& Wilson, 2007). 
Ayu Yuliani S., Poltekkes Tasikmalaya.; Pendampingan, kooperatif, usia prasekolah, invasif,

\section{KESIMPULAN}

Terdapat

hubungan anatara pendampingan orang tua dengan tingkat kooperatif anak usia prasekolah (3-6) tahun selama pemberian tindakan invasif injeksi intravena di ruang IGD RSUD Arjawinangun Kabupaten Cirebon dengan nilai pvalue 0,050 . Sebagian besar responden didamping oleh orang tuanya. Proposi responden lebih banyak anak yang berusia 3 tahun dengan

\section{SARAN}

Pendampingan orang tua dapat digunakan sebagai acuan untuk melakukan intervensi keperawatan anak dengan prinsip atraumatic care di rumah sakit dalam mengatasi tingkat kooperatif anak selama tindakan invasif injeksi intravena.

Perlu ditingkatkan kemampuan perawat dalam mengidentifikasi berbagai masalah yang dialami anak yang sakit, tidak hanya faktor fisik tetapi juga faktor psikologis. Perawat diharapkan dapat melakukan asuhan keperawatan anak dengan prinsip atraumatic care. Diharapkan dari penerapan prinsip tersebut perawat beserta keluarga terutama orang tua dapat bekerjasama untuk memberikan rasa aman kepada anak selama

\section{Daftar Referensi}

Cahyaningrum, D.S., (2011). Pertumbuhan perkembangan anak dan remaja. Jakarta: CV. Trans Info Media

Carpenito, L.J.. (2009) Diagnosa Keperawatan Aplikasi Pada Praktek Klinis.Jakarta : EGC

Hockenberry, J.M, \& Wilson, D., (2009). Essentials Of Pediatric Nursing. St. Louis : Mosby An Affilite of Elseveir inc

Nursalam, Rekawati, S \& Utami, S., (2005). Asuhan Keperawatan Bayi dan Anak. Jakarta: Salemba Medika

Profil Kesehatan Kab. Cirebon, (2011) Diambil pada 26 Februari 2014 dari http://dinkes.cirebonkab.go.id. jenis kelamin laki-laki lebih mendominasi. Nilai signifikasi positif menunjukan semakin besar variabel pendampingan orang tua akan semakin besar hubungan tingkat kooperatif anak yang dilakukan injeksi intravena sementara pada variabel sedangkan pada jenis kelamin tidak ditemukan hubungan yang dapat mempengaruhi tingkat kooperatif anak.

pemberian prosedur invasif yang notabennya dapat menimbulkan traumatic

Intervensi yang dapat dilakukan perawat untuk meningkatkan tingkat kooperatif anak yaitu dengan mengikutsertakan keluarga dalam proses keperawatan terutama, proses yang dapat mencederai dan membuat takut. Selain itu alangkah baiknya modifikasi lingkungan yang membuat anak merasa nyaman meski sedang dalam kondisi hospitalisasi

Perlu dilakukan penelitian lebih lanjut tentang pendampingan orang tua dengan tingkat kooperatif anak, usia dan pengalaman hospitalisasi terhadap tingkat kooperatif anak yang dirawat di ruang anak dengan menggunakan metode eksperimen

Supartini, Y., (2004). Buku Ajar Konsep Dasar Keperawatan Anak.Jakarta: EGC

Subandi, A., (2012). Pengaruh pemasangan spalk bermotif terhadap tingkat kooperatif anak usia prasekolah selama prosedur injeksi intravena di Rumah Sakit Wilayah Cilacap. diakses pada tanggal 4 Desember 2015.

Wong D.L., (2008). Buku Ajar Keperawatan Pediatrik .Jakarta : EGC.

Wong, D. L., Hockenberry, M., Eaton, Wilson, D., Winkelstein, M. L., \& Schwartz, P. (2009). Buku ajar: Keperawatan pediatrik. Edisi 6. Alih bahasa: Hartono. A., Kurnianingsih. S., \& Setiawan. Jakarta: EGC. 